\title{
MENUMBUHKAN KREATIVITAS SISWA MELALUI PEMBELAJARAN GRAFIK FUNGSI EKSPONEN DENGAN PENDEKATAN OPEN-ENDED PROBLEM
}

\author{
EKO PURWANTO
}

SMA Negeri 1 Tanjung Palas

Email : eko.borneo@gmail.com

\begin{abstract}
ABSTRAK
Standar Isi Kurikulum Tingkat Satuan Pendidikan (KTSP) mengamanatkan pentingnya menumbuhkan kreativitas siswa, kemampuan memiliki sikap kreatif dan berpikir kreatif melalui kegiatan kreatif dalam pembelajaran matematika. Salah satu cara yang dapat dilakukan untuk menumbuhkan kreativitas adalah melalui pembelajaran eksponen fungsi grafik dengan menggunakan pendekatan open-ended problem terhadap masalah tersebut. Pendekatan openended problem membutuhkan pemecahan masalah terbuka dan kreativitas siswa untuk memecahkan masalah dengan lebih dari satu jawaban yang benar. Proses penelitian menggunakan desain penelitian tindakan kelas yang bertujuan untuk menjelaskan pembelajaran grafik fungsi eksponen dengan pendekatan open-ended problem untuk menumbuhkan kreativitas siswa, yaitu aspek sikap kreatif dan berpikir kreatif siswa serta mengetahui respon siswa setelah diajar dengan menggunakan pendekatan open-ended problem. Sasaran penelitian adalah siswa kelas XII IPA SMA Negeri 1 Tanjung Selor tahun ajaran 2010/2011. Pengumpulan data melalui angket, lembar observasi, wawancara, dan tes. Berdasarkan hasil penelitian diperoleh bahwa pembelajaran grafik fungsi eksponen dengan pendekatan openended problem dapat menumbuhkan sikap kreatif dan berpikir kreatif siswa dengan persentase rata-rata 73,35\% dari 30 siswa dan termasuk dalam kategori kreatif. Berdasarkan hasil tes akhir dan tugas siswa, diperoleh hasil bahwa rata-rata siswa mampu menjawab semua soal tes yang diujikan, walaupun tidak sepenuhnya benar, namun setidaknya siswa telah memberikan beberapa alternatif jawaban yang benar dalam menyelesaikan soal-soal tes yang diujikan. Aktivitas guru dalam pembelajaran memperoleh kategori sangat baik dengan persentase 88,3\% dan respon siswa positif terhadap pembelajaran grafik fungsi eksponen melalui pendekatan open-ended problem dengan skor rata-rata kumulatif 4,49.
\end{abstract}

Kata kunci : Grafik Fungsi Eksponen, Pendekatan open-ended problem, Kreativitas, yakni aspek sikap kreatif dan berpikir kreatif.

\section{PENDAHULUAN}

Kreativitas siswa adalah kemampuan siswa/subyek untuk menginteraksikan antara sikap, proses, dan lingkungan sehingga menghasilkan suatu gagasan/ide yang dinilai baru dan berguna dalam konteks sosialnya/lingkungannya. Untuk menumbuhkan kreativitas siswa dalam pembelajaran merupakan permasalahan pembelajaran yang sering timbul dari guru di kelas. Padahal diketahui bahwa setiap orang yang dilahirkan di dunia pada dasarnya memiliki potensi kreatif dan dapat diidentifikasi dan dipupuk melalui pendidikan yang tepat (Munandar, 2009:12). Menurut Aziz (2010:3), permasalahan sulitnya menumbuhkan kreativitas siswa karena kenyataan yang ada bahwa pendidikan di Indonesia saat ini lebih berorientasi pada hasil yang bersifat pengulangan, penghapalan, dan pencarian satu jawaban yang benar terhadap soalsoal yang diberikan. Kenyataan menunjukkan bahwa siswa di sekolah dasar dan menengah kurang sekali diberikan bahan pelajaran dan soal-soal yang berkaitan dengan pemecahan dan penyelesaian masalah, contohnya guru lebih sering menuntut siswa menghafalkan rumusrumus dan mengerjakan soal-soal matematika yang kurang meningkatkan kemampuan bernalar (reasoning), tetapi cenderung meningkatkan kemampuan mengingatnya saja. Padahal banyak manfaat dari pengalaman memecahkan dan menyelesaikan masalah, antara lain adalah siswa menjadi: (1) kreatif dalam berpikir, (2) kritis dalam menganalisis data, fakta, dan informasi, dan (3) mandiri dalam bertindak dan bekerja (Muhsetyo, 2004:128). 
Permasalahan sulitnya menumbuhkan kreativitas siswa juga dialami oleh penulis saat mengajar di SMA Negeri 1 Tanjung Selor, yaitu pada saat melaksanakan pembelajaran matematika di sekolah. Berdasarkan hasil dialog dengan guru matematika di SMA Negeri 1 Tanjung Selor, bahwa dalam belajar matematika siswa SMA Negeri 1 Tanjung Selor mempunyai kecenderungan belajar yang sifatnya pengulangan, penghapalan, dan pencarian satu jawaban yang benar terhadap soal-soal yang diberikan. Menurut Joni (dalam Aziz, 2010:3), bahwa proses-proses pemikiran tingkat tinggi termasuk kreativitas siswa dalam hal berpikir kreatif jarang sekali dilatihkan di sekolah menengah. Sebagai indikatornya adalah siswa sekolah menengah tidak mempunyai inisiatif untuk mengerjakan soal-soal matematika selain yang diberikan guru di kelas, memberikan alternatif jawaban pada saat menyelesaikan soal/masalah matematika, mengemukakan ide pemecahan dan penyelesaian masalah yang berbeda dari siswa lain saat diskusi kelas.

Berdasarkan hasil wawancara terbatas dengan beberapa siswa SMA Negeri 1 Tanjung Selor, bahwa faktor penyebabnya adalah: (1) pemberian soal-soal (masalah) yang tidak menantang bagi mereka untuk mencari buku referensi, (2) mereka berpendapat bahwa dalam menyelesaikan permasalahan hanya berpedoman pada contoh-contoh soal yang diberikan pada saat belajar di kelas yang tidak membutuhkan beberapa alternatif penyelesaian, dan (3) pada saat diskusi, siswa kurang diberikan kesempatan untuk mengemukakan idenya, ide didominasi oleh guru. Untuk menumbuhkembangkan kebiasaan belajar secara berkesinambungan dan terarah, pada akhirnya dapat menumbuhkan kreativitas siswa dalam belajar, maka guru perlu mengadakan suatu perbaikan pembelajaran yang berorientasi pada siswa (student oriented). Pembelajaran berorientasi pada siswa diharapkan mampu mendorong (press) tumbuhnya kreativitas dalam diri siswa, baik dalam bentuk kemampuan bersikap kreatif maupun kemampuan berpikir kreatif.

Salah satu model pembelajaran yang berorientasi pada siswa dan diharapkan mampu menumbuhkan kreativitas siswa adalah pemecahan masalah. Menurut Koseki (dalam Muhsetyo, 2004:128), salah satu kegiatan dalam pemecahan masalah, yaitu exploring openended problem. Selanjutnya menurut Shimada (1997:1), bahwa pendekatan open-ended adalah pendekatan pembelajaran yang menyajikan suatu permasalahan yang memiliki metode atau penyelesaian yang benar lebih dari satu, sehingga siswa mempunyai kesempatan untuk memperoleh pengetahuan menemukan, mengenali, dan memecahkan masalah dengan beberapa tehnik, khususnya masalah/soal-soal matematika.

Penulis selanjutnya melakukan penelitiannya dengan fokus melihat tumbuhnya kreativitas siswa sebagai dampak digunakannya pendekatan open-ended problem dalam pembelajaran pada materi grafik fungsi eksponen. Pemilihan materi grafik fungsi eksponen dikarenakan dalam pembelajaran materi tersebut guru sering menyampaikan konsep-konsep yang terdapat dalam materi grafik fungsi eksponen dengan ceramah dan sekedar ditransfer dari guru ke siswa, dan siswa secara pasif menerima konsep-konsep tersebut. Penulis yakin bahwa pembelajaran materi grafik fungsi eksponen dengan menggunakan pendekatan openended problem dapat menjadi sarana atau faktor pendorong (press) untuk menumbuhkan kreativitas siswa. Hal tersebut karena pendekatan open-ended problem banyak melibatkan siswa secara aktif berpikir baik secara fisik maupun mental. Sebagai contoh pertanyaan "Gambar sketsa grafik $y=3^{x}, y=4^{x}$, untuk semua x anggota bilangan real. Sebutkan 4 sifat dari sketsa grafik-grafik tersebut yang sama”, kemudian pertanyaan tersebut diubah menjadi pertanyaan yang bersifat open-ended sebagai berikut: "Diketahui suatu fungsi eksponen $y=a^{x}, a>1$, untuk semua $x$ anggota bilangan real. Misalkan a $=2$ diperoleh $y=2^{x}$. Pilih paling sedikit tiga nilai a yang berbeda dan mempunyai sifat yang sama dengan fungsi $y=2^{x}$. Kemudian sebutkan sebanyak-sebanyaknya alasan mengapa dikatakan sama". Dengan pertanyaan tersebut secara fisik siswa melakukan aktivitas menggambar grafik fungsi eksponen dengan berbagai nilai a, sedangkan secara mental siswa aktif dan kreatif untuk menemukan hubungan-hubungan dari berbagai gambar grafik fungsi eksponen yang dibuat. 
Berdasarkan latar belakang yang telah diuraikan, maka tujuan penelitian adalah untuk mendeskripsikan cara menumbuhkan kreativitas siswa pada dimensi pribadi, yaitu aspek sikap kreatif dan berpikir kreatif melalui pembelajaran grafik fungsi eksponen dengan pendekatan open-ended problem.

\section{METODE PENELITIAN}

Metode penelitian yang digunakan adalah metode penelitian kualitatif. Penulis bertindak sebagai instrumen kunci karena penulis yang merencanakan, merancang, melaksanakan, mengumpulkan data, menganalisis data, menarik kesimpulan, dan membuat laporan (Moleong, 2007). Prosedur penelitian menghasilkan data deskriptif berupa uraian yang menjelaskan prosedur pembelajaran grafik fungsi eksponen dengan pendekatan open-ended problem yang dapat menumbuhkan kreativitas siswa. Analisis data dilakukan secara induktif. Jenis penelitian yang digunakan adalah penelitian tindakan kelas (PTK). Berikut model rancangan penelitian tindakan kelas:

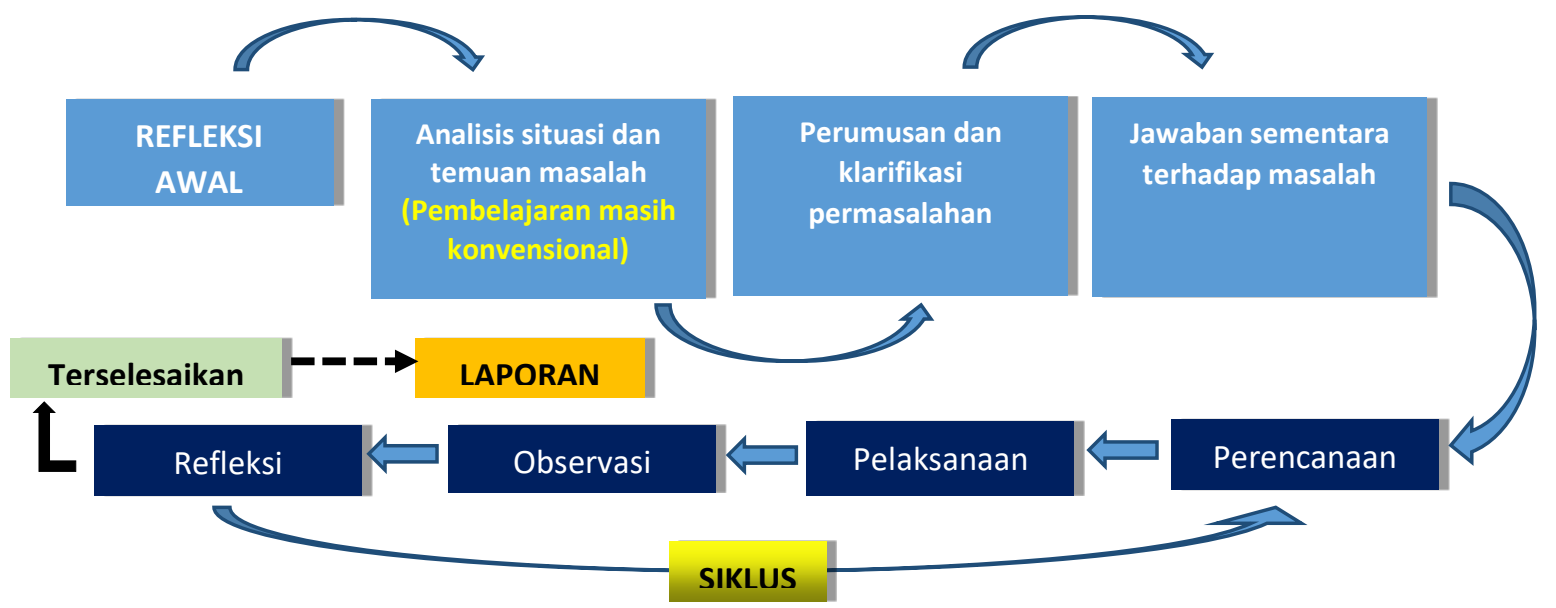

Gambar I : Model Rancangan Penelitian Tindakan Kelas

Model rancangan penelitian tindakan kelas dilaksanakan dalam empat tahap, yaitu: perencanaan, pelaksanaan, observasi, dan refleksi yang berlangsung dalam siklus atau kegiatan berulang. Siklus berikutnya dilakukan apabila siklus yang baru dilaksanakan dianggap tidak berhasil sesuai indikator keberhasilan yang ditetapkan (Ghony, 2008:15).

Prosedur pengumpulan data berupa pengamatan (observasi) aktivitas siswa dan aktivitas guru, wawancara, angket, dan tes hasil belajar siswa. Perangkat penelitian yang digunakan adalah lembar observasi, format wawancara, lembar angket, instrumen tes, rencana pembelajaran, dan lembar kerja siswa. Indikator keberhasilan dalam penelitian adalah keberhasilan penulis untuk menelusuri, mendalami, dan menyelesaikan temuan-temuan yang diperoleh dari data dan fakta di lapangan, seperti ada kesalahan-kesalahan konseptual pada hasil kerja siswa, sehingga mereka perlu diperiksa ulang dan diwawancarai. Keberhasilan dalam penelitian juga menggunakan ketiga indikator berikut: (1) apabila skor aktivitas guru dalam pembelajaran berada pada kategori baik, (2) apabila penulis dapat menumbuhkan kreativitas siswa untuk aspek sikap kreatif dan berpikir kreatif minimal 65\% dari jumlah siswa dalam kelas penelitian dan berada dalam kategori kreatif pada akhir siklus tindakan, dan (3) apabila respon siswa dalam kategori positif selama mengikuti pembelajaran dengan pendekatan open-ended problem pada grafik fungsi eksponen. 


\section{HASIL DAN PEMBAHASAN}

Hasil

Data penelitian pada tindakan siklus I :

Tabel 1: Hasil Observasi Aktivitas Guru

\begin{tabular}{|l|l|c|c|}
\hline No. & $\begin{array}{c}\text { Tahapan } \\
\text { Pembelajaran }\end{array}$ & $\begin{array}{c}\text { Observer } \\
\text { I }\end{array}$ & $\begin{array}{c}\text { Observer } \\
\text { II }\end{array}$ \\
\cline { 3 - 4 } & Skor & Skor \\
\hline 1. & Tahap Awal*) & 36 & 39 \\
\hline 2. & Tahap Inti*) & 210 & 215 \\
\hline 3. & Tahap Akhir*) & 64 & 67 \\
\hline \multicolumn{2}{|l|}{ Jumlah Skor } & $\mathbf{3 1 0}$ & $\mathbf{3 2 1}$ \\
\hline \multicolumn{2}{|l|}{ Persentase nilai rata-rata (x) } & $\mathbf{8 7 , 3 \%}$ & $\mathbf{8 9 , 2 \%}$ \\
\hline Kategori & Baik & Baik \\
\hline
\end{tabular}

Keterangan:*) Indikator :

1. Tahap Inti
a) Mengajukan masalah open ended.
b) Menyediakan sarana yang diperlukan siswa
c) Membimbing dan mengarahkan siswa untuk masalah open ended (LKS)
d) Menbentuk kelompok-kelompok kecil untuk diskusi
e) Mengamati kreativitas siswa dalam diskusi kelompok(asesmen proses) bersama observer.
f) Mempersilakan setiap kelompok menyajikan hasil kerja kelompok.

Kategori Observasi Aktivitas Guru :

$90 \%<\mathrm{x} \leq 100 \%=$ Sangat baik, $80 \%<\mathrm{x} \leq 90 \%=$ Baik, $70 \%<\mathrm{x} \leq 80 \%=$ Cukup baik, $60 \%<\mathrm{x} \leq 70 \%=$ Kurang, $0 \%<\mathrm{x} \leq 60 \%=$ Sangat kurang,

Berdasarkan hasil observasi, observer I memberikan skor 310 dan observer II memberikan skor 321 dengan skor maksimum 360. Observer I memberikan nilai persentase sebesar $87,3 \%$ dan observer II memberikan nilai persentase sebesar 89,2\%. Rata-rata nilai persentase adalah $88,3 \%$, sehingga aktivitas guru sebesar $88,3 \%$ dalam kategori baik.

Tabel 2 : Hasil Observasi Kreativitas Siswa (Bagian 1)

\begin{tabular}{|c|c|c|c|c|c|c|c|c|c|c|c|c|c|c|c|c|}
\hline \multicolumn{17}{|c|}{ SIKAP KREATIF } \\
\hline Aspek & \multicolumn{2}{|c|}{$\mathbf{N}$} & \multicolumn{2}{|c|}{ DPP } & \multicolumn{2}{|c|}{ RS } & \multicolumn{2}{|c|}{ NIK } & \multicolumn{2}{|c|}{ AF } & \multicolumn{2}{|c|}{ DRS } & \multicolumn{2}{|c|}{ IRW } & \multicolumn{2}{|c|}{ RH } \\
\hline Observer & I & II & I & II & I & II & I & II & I & II & I & II & I & II & I & II \\
\hline 1 & 5 & 4 & 5 & 5 & 5 & 5 & 5 & 5 & 5 & 4 & 5 & 5 & 3 & 3 & 5 & 5 \\
\hline $2 a$ & 4 & 4 & 2 & 3 & 4 & 4 & 2 & 2 & 2 & 3 & 2 & 3 & 2 & 2 & 2 & 3 \\
\hline $2 \mathbf{b}$ & 4 & 4 & 5 & 5 & 1 & 2 & 1 & 2 & 4 & 4 & 2 & 2 & 1 & 2 & 5 & 5 \\
\hline 3a & 5 & 5 & 5 & 5 & 4 & 4 & 4 & 4 & 4 & 5 & 4 & 4 & 4 & 4 & 5 & 5 \\
\hline $3 \mathbf{b}$ & 3 & 3 & 3 & 3 & 2 & 2 & 2 & 3 & 4 & 4 & 3 & 3 & 3 & 3 & 2 & 2 \\
\hline 4 & 4 & 4 & 5 & 5 & 3 & 3 & 3 & 3 & 4 & 4 & 3 & 4 & 3 & 3 & 5 & 5 \\
\hline 5 & 5 & 5 & 2 & 2 & 5 & 5 & 1 & 1 & 5 & 5 & 5 & 5 & 5 & 5 & 5 & 5 \\
\hline 6 & 5 & 5 & 5 & 5 & 5 & 5 & 5 & 5 & 4 & 4 & 4 & 4 & 4 & 4 & 5 & 5 \\
\hline $\begin{array}{c}\text { Jml Skor } \\
\text { (J1) }\end{array}$ & 35 & 34 & 32 & 33 & 29 & 30 & 23 & 25 & 32 & 33 & 28 & 30 & 25 & 26 & 34 & 35 \\
\hline \multicolumn{17}{|c|}{ BERPIKIR KREATIF } \\
\hline Aspek & \multicolumn{2}{|c|}{$\mathbf{N}$} & \multicolumn{2}{|c|}{ DPP } & \multicolumn{2}{|c|}{ RS } & \multicolumn{2}{|c|}{ NIK } & \multicolumn{2}{|c|}{$\mathbf{A F}$} & \multicolumn{2}{|c|}{ DRS } & \multicolumn{2}{|c|}{ IRW } & \multicolumn{2}{|c|}{ RH } \\
\hline Observer & I & II & I & II & I & II & I & II & I & II & I & II & I & II & I & II \\
\hline 1 & 2 & 3 & 2 & 2 & 3 & 3 & 1 & 1 & 2 & 2 & 3 & 3 & 2 & 2 & 2 & 2 \\
\hline 2 & 2 & 3 & 2 & 2 & 3 & 3 & 1 & 1 & 2 & 2 & 3 & 3 & 2 & 2 & 2 & 2 \\
\hline
\end{tabular}


Vol. 1 No. 2 Agustus 2021, e-ISSN : 2777-0575 P-ISSN : 2777-0583

\begin{tabular}{|c|c|c|c|c|c|c|c|c|c|c|c|c|c|c|c|c|}
\hline $\mathbf{3}$ & 4 & 4 & 2 & 2 & 2 & 2 & 1 & 1 & 4 & 4 & 3 & 4 & 2 & 2 & 2 & 2 \\
\hline $\mathbf{4}$ & 4 & 4 & 4 & 4 & 4 & 3 & 2 & 3 & 4 & 4 & 4 & 4 & 2 & 2 & 2 & 2 \\
\hline $\begin{array}{c}\text { Jml Skor } \\
(\mathbf{J 2})\end{array}$ & $\mathbf{1 2}$ & $\mathbf{1 4}$ & $\mathbf{1 0}$ & $\mathbf{1 0}$ & $\mathbf{1 2}$ & $\mathbf{1 1}$ & $\mathbf{5}$ & $\mathbf{6}$ & $\mathbf{1 2}$ & $\mathbf{1 2}$ & $\mathbf{1 3}$ & $\mathbf{1 4}$ & $\mathbf{8}$ & $\mathbf{8}$ & $\mathbf{8}$ & $\mathbf{8}$ \\
\hline $\begin{array}{c}\text { Total } \\
(\mathbf{J 1 + J 2})\end{array}$ & 47 & 48 & 42 & 43 & 41 & 41 & 28 & 31 & 44 & 45 & 41 & 44 & 33 & 34 & 42 & 43 \\
\hline Kategori & $\mathbf{K}$ & $\mathbf{K}$ & $\mathbf{K}$ & $\mathbf{K}$ & $\mathbf{K}$ & $\mathbf{K}$ & $\mathbf{T K}$ & $\mathbf{C K}$ & $\mathbf{K}$ & $\mathbf{K}$ & $\mathbf{K}$ & $\mathbf{K}$ & $\mathbf{C K}$ & $\mathbf{C K}$ & $\mathbf{K}$ & $\mathbf{K}$ \\
\hline
\end{tabular}

Tabel 3 : Hasil Observasi Kreativitas Siswa (Bagian 2)

\begin{tabular}{|c|c|c|c|c|c|c|c|c|c|c|c|c|c|c|c|c|}
\hline \multicolumn{17}{|c|}{ SIKAP KREATIF } \\
\hline Aspek & \multicolumn{2}{|c|}{ FEW } & \multicolumn{2}{|c|}{ AAS } & \multicolumn{2}{|c|}{ TFR } & \multicolumn{2}{|c|}{ SI } & \multicolumn{2}{|c|}{ SD } & \multicolumn{2}{|c|}{ SH } & \multicolumn{2}{|c|}{ ER } & \multicolumn{2}{|c|}{ JPK } \\
\hline Observer & I & II & I & II & I & II & I & II & I & II & I & II & I & II & I & II \\
\hline 1 & 5 & 4 & 5 & 5 & 5 & 5 & 5 & 5 & 3 & 3 & 3 & 4 & 3 & 3 & 2 & 2 \\
\hline $2 a$ & 4 & 4 & 2 & 2 & 5 & 5 & 2 & 2 & 4 & 4 & 4 & 4 & 2 & 2 & 2 & 2 \\
\hline $2 \mathbf{b}$ & 4 & 4 & 4 & 4 & 5 & 5 & 1 & 2 & 4 & 4 & 5 & 5 & 4 & 4 & 1 & 1 \\
\hline $3 \mathbf{a}$ & 4 & 4 & 3 & 4 & 5 & 5 & 4 & 4 & 4 & 5 & 5 & 4 & 4 & 4 & 5 & 4 \\
\hline $3 \mathbf{b}$ & 3 & 3 & 5 & 5 & 5 & 4 & 4 & 4 & 4 & 3 & 3 & 3 & 3 & 3 & 2 & 2 \\
\hline 4 & 3 & 3 & 3 & 3 & 5 & 5 & 3 & 3 & 4 & 4 & 5 & 5 & 4 & 4 & 3 & 3 \\
\hline 5 & 5 & 5 & 2 & 2 & 5 & 5 & 1 & 2 & 5 & 5 & 1 & 1 & 5 & 5 & 1 & 1 \\
\hline 6 & 5 & 5 & 5 & 5 & 5 & 5 & 4 & 4 & 5 & 4 & 4 & 4 & 4 & 4 & 4 & 3 \\
\hline $\begin{array}{c}\text { Jml Skor } \\
(\mathbf{J} 1)\end{array}$ & 33 & 32 & 29 & 30 & 40 & 39 & 24 & 26 & 33 & 32 & 30 & 30 & 29 & 29 & 20 & 18 \\
\hline \multicolumn{17}{|c|}{ BERPIKIR KREATIF } \\
\hline Aspek & \multicolumn{2}{|c|}{ FEW } & \multicolumn{2}{|c|}{ AAS } & \multicolumn{2}{|c|}{ TFR } & \multicolumn{2}{|c|}{ SI } & \multicolumn{2}{|c|}{ SD } & \multicolumn{2}{|c|}{ SH } & \multicolumn{2}{|c|}{ ER } & \multicolumn{2}{|c|}{ JPK } \\
\hline Observer & $\mathrm{I}$ & II & $\mathrm{I}$ & II & $\mathrm{I}$ & II & $\mathrm{I}$ & II & $\mathrm{I}$ & II & $\mathrm{I}$ & II & $\mathrm{I}$ & II & $\mathrm{I}$ & II \\
\hline 1 & 2 & 3 & 4 & 4 & 5 & 5 & 5 & 5 & 4 & 4 & 2 & 2 & 3 & 3 & 2 & 2 \\
\hline 2 & 2 & 3 & 4 & 4 & 5 & 3 & 5 & 5 & 4 & 4 & 2 & 2 & 3 & 3 & 2 & 2 \\
\hline 3 & 2 & 2 & 5 & 5 & 2 & 2 & 3 & 3 & 4 & 3 & 2 & 2 & 2 & 2 & 2 & 2 \\
\hline 4 & 4 & 4 & 4 & 4 & 4 & 4 & 4 & 4 & 4 & 4 & 3 & 4 & 3 & 2 & 2 & 2 \\
\hline $\begin{array}{c}\text { Jml Skor } \\
(\text { J2) }\end{array}$ & 10 & 12 & 17 & 17 & 16 & 16 & 17 & 17 & 16 & 15 & 9 & 10 & 11 & 10 & 8 & 8 \\
\hline $\begin{array}{l}\text { Total } \\
(\mathrm{J} 1+\mathrm{J} 2)\end{array}$ & 43 & 44 & 46 & 47 & 56 & 55 & 41 & 43 & 49 & 47 & 39 & 40 & 40 & 39 & 28 & 26 \\
\hline Kategori & $\mathbf{K}$ & $\mathbf{K}$ & $\mathbf{K}$ & $\mathbf{K}$ & SK & SK & $\mathbf{K}$ & $\mathbf{K}$ & $\mathbf{K}$ & $\mathbf{K}$ & CK & $\mathbf{K}$ & $\mathbf{K}$ & CK & TK & TK \\
\hline
\end{tabular}

Tabel 4 : Hasil Observasi Kreativitas Siswa (Bagian 3)

\begin{tabular}{|c|c|c|c|c|c|c|c|c|c|c|c|c|c|c|c|c|}
\hline \multicolumn{17}{|c|}{ SIKAP KREATIF } \\
\hline Aspek & \multicolumn{2}{|c|}{ DC } & \multicolumn{2}{|c|}{ EP } & \multicolumn{2}{|c|}{ IR } & \multicolumn{2}{|c|}{ MR } & \multicolumn{2}{|c|}{ KN } & \multicolumn{2}{|c|}{ B } & \multicolumn{2}{|c|}{ SAP } & \multicolumn{2}{|c|}{ MJ } \\
\hline Observer & $\mathrm{I}$ & II & $\mathrm{I}$ & II & I & II & $\mathrm{I}$ & II & $\mathrm{I}$ & II & I & II & $\mathrm{I}$ & II & $\mathrm{I}$ & II \\
\hline 1 & 5 & 5 & 5 & 5 & 5 & 5 & 3 & 4 & 5 & 5 & 5 & 4 & 5 & 5 & 4 & 3 \\
\hline $2 \mathbf{a}$ & 5 & 5 & 2 & 2 & 2 & 2 & 2 & 3 & 5 & 5 & 2 & 2 & 4 & 4 & 2 & 2 \\
\hline $2 b$ & 5 & 5 & 1 & 1 & 1 & 1 & 3 & 2 & 5 & 5 & 2 & 2 & 1 & 1 & 1 & 1 \\
\hline $3 \mathbf{a}$ & 5 & 5 & 3 & 3 & 5 & 5 & 3 & 3 & 5 & 5 & 3 & 3 & 5 & 5 & 4 & 4 \\
\hline $\mathbf{3 b}$ & 5 & 5 & 2 & 2 & 2 & 2 & 3 & 3 & 5 & 5 & 2 & 2 & 3 & 3 & 3 & 3 \\
\hline 4 & 5 & 5 & 3 & 3 & 4 & 4 & 4 & 4 & 5 & 5 & 4 & 4 & 4 & 5 & 3 & 4 \\
\hline 5 & 2 & 2 & 5 & 5 & 3 & 3 & 3 & 3 & 5 & 5 & 1 & 1 & 4 & 4 & 5 & 5 \\
\hline 6 & 5 & 5 & 5 & 5 & 5 & 4 & 4 & 4 & 4 & 5 & 5 & 4 & 4 & 4 & 2 & 3 \\
\hline $\begin{array}{c}\text { Jml Skor } \\
\text { (J1) }\end{array}$ & 37 & 37 & 26 & 26 & 27 & 26 & 24 & 26 & 39 & 40 & 24 & 22 & 30 & 33 & 24 & 25 \\
\hline
\end{tabular}


Vol. 1 No. 2 Agustus 2021, e-ISSN : 2777-0575 P-ISSN : 2777-0583

\begin{tabular}{|c|c|c|c|c|c|c|c|c|c|c|c|c|c|c|c|c|}
\hline Aspek & \multicolumn{2}{|c|}{ DC } & \multicolumn{2}{|c|}{ EP } & \multicolumn{2}{|c|}{ IR } & \multicolumn{2}{|c|}{ MR } & \multicolumn{2}{|c|}{ KN } & \multicolumn{2}{|c|}{ B } & \multicolumn{2}{|c|}{ SAP } & \multicolumn{2}{|c|}{ MJ } \\
\hline Observer & I & II & I & II & I & II & I & II & I & II & I & II & I & II & I & II \\
\hline 1 & 2 & 3 & 3 & 3 & 2 & 2 & 5 & 5 & 3 & 3 & 2 & 2 & 3 & 3 & 3 & 3 \\
\hline 2 & 2 & 3 & 3 & 3 & 2 & 2 & 5 & 5 & 3 & 3 & $\pi$ & 2 & 3 & 3 & 3 & 3 \\
\hline 3 & 2 & 2 & 5 & 4 & 2 & 2 & 4 & 4 & 2 & 2 & 2 & 2 & 2 & 2 & 2 & 3 \\
\hline 4 & 4 & 4 & 3 & 3 & 3 & 4 & 3 & 3 & 4 & 4 & 2 & 8 & 4 & 4 & 4 & 4 \\
\hline $\begin{array}{c}\text { Jml Skor } \\
\text { (J2) }\end{array}$ & 10 & 12 & 14 & 13 & 9 & 10 & 17 & 17 & 12 & 12 & 9 & 9 & 12 & 12 & 12 & 13 \\
\hline $\begin{array}{c}\text { Total } \\
(\mathbf{J} 1+\mathbf{J} 2)\end{array}$ & 47 & 49 & 40 & 39 & 36 & 36 & 41 & 43 & 51 & 52 & 33 & 31 & 42 & 45 & 36 & 38 \\
\hline Kategori & $\mathbf{K}$ & $\mathbf{K}$ & $\mathbf{K}$ & CK & CK & CK & $\mathbf{K}$ & $\mathbf{K}$ & SK & SK, & CK & CK & $\mathbf{K}$ & $\mathbf{K}$ & CK & CK \\
\hline
\end{tabular}

Tabel 5: Hasil Observasi Kreativitas Siswa (Bagian 4)

\begin{tabular}{|c|c|c|c|c|c|c|c|c|c|c|c|c|}
\hline \multicolumn{13}{|c|}{ SIKAP KREATIF } \\
\hline Aspek & \multicolumn{2}{|c|}{ JPM } & \multicolumn{2}{|c|}{ GAP } & \multicolumn{2}{|c|}{ NFS } & \multicolumn{2}{|c|}{ YD } & \multicolumn{2}{|c|}{ MN } & \multicolumn{2}{|c|}{ ANS } \\
\hline Observer & $\mathrm{I}$ & II & $\mathrm{I}$ & II & $\mathrm{I}$ & II & $\mathrm{I}$ & II & $\mathrm{I}$ & II & $\mathrm{I}$ & II \\
\hline 1 & 2 & 2 & 5 & 5 & 5 & 5 & 5 & 4 & 5 & 5 & 5 & 4 \\
\hline $2 a$ & 2 & 3 & 5 & 5 & 2 & 2 & 4 & 4 & 2 & 2 & 2 & 4 \\
\hline $2 \mathbf{b}$ & 1 & 2 & 5 & 5 & 1 & 2 & 4 & 4 & 1 & 2 & 3 & 2 \\
\hline $3 \mathbf{a}$ & 4 & 4 & 5 & 5 & 4 & 4 & 5 & 5 & 3 & 4 & 4 & 3 \\
\hline $3 \mathbf{b}$ & 3 & 3 & 5 & 5 & 2 & 3 & 4 & 4 & 3 & 3 & 3 & 3 \\
\hline 4 & 3 & 3 & 5 & 5 & 3 & 5 & 4 & 3 & 3 & 4 & 4 & 3 \\
\hline 5 & 5 & 5 & 5 & 5 & 5 & 5 & 5 & 5 & 5 & 5 & 5 & 5 \\
\hline 6 & 4 & 4 & 5 & 5 & 5 & 5 & 5 & 5 & 5 & 5 & 4 & 4 \\
\hline $\begin{array}{c}\text { Jml Skor } \\
\text { (J1) }\end{array}$ & 24 & 26 & 40 & 40 & 27 & 31 & 36 & 34 & 27 & 30 & 30 & 28 \\
\hline \multicolumn{13}{|c|}{ BERPIKIR KREATIF } \\
\hline Aspek & \multicolumn{2}{|c|}{ JPM } & \multicolumn{2}{|c|}{ GAP } & \multicolumn{2}{|c|}{ NFS } & \multicolumn{2}{|c|}{ YD } & \multicolumn{2}{|c|}{ MN } & \multicolumn{2}{|c|}{ ANS } \\
\hline Observer & $\mathrm{I}$ & II & $\mathrm{I}$ & II & $\mathrm{I}$ & II & $\mathrm{I}$ & II & $\mathrm{I}$ & II & $\mathrm{I}$ & II \\
\hline 1 & 4 & 4 & 5 & 5 & 3 & 3 & 5 & 4 & 4 & 3 & 2 & 2 \\
\hline 2 & 4 & 4 & 5 & 5 & 3 & 3 & 5 & 4 & 4 & 3 & 2 & 2 \\
\hline 3 & 5 & 5 & 5 & 5 & 5 & 5 & 5 & 5 & 5 & 5 & 4 & 4 \\
\hline 4 & 4 & 4 & 4 & 4 & 3 & 4 & 4 & 4 & 3 & 3 & 3 & 3 \\
\hline $\begin{array}{c}\text { Jml Skor } \\
(\mathbf{J} 2)\end{array}$ & 17 & 17 & 19 & 19 & 14 & 15 & 19 & 17 & 16 & 14 & 11 & 11 \\
\hline $\begin{array}{c}\text { Total } \\
(\mathrm{J} 1+\mathrm{J} 2)\end{array}$ & 48 & 43 & 59 & 59 & 41 & 46 & 55 & 51 & 43 & 44 & 41 & 39 \\
\hline Kategori & $\mathbf{K}$ & $\mathbf{K}$ & SK & SK & $\mathbf{K}$ & $\mathbf{K}$ & SK & SK & $\mathbf{K}$ & $\mathbf{K}$ & $\mathbf{K}$ & CK \\
\hline
\end{tabular}

Keterangan : SK=Sangat Kreatif, K=Kreatif, CK=Cukup Kreatif, TK=Tidak Kreatif Aspek Sikap Kreatif : 
Berdasarkan data observasi kreativitas siswa, observer I memperoleh 4 orang siswa dalam kategori sangat kreatif dan 19 orang siswa dalam kategori kreatif dengan persentase gabungan kedua kategori adalah 76,7\%, observer II memperoleh 4 orang siswa dalam kategori sangat kreatif dan 17 orang siswa dalam kategori kreatif dengan persentase gabungan kedua kategori adalah $70 \%$. Rata -rata persentase dari kedua observer adalah 73,5\%, sehingga masuk dalam kategori kreatif.

Tabel 6 : Hasil Angket Respon Siswa Terhadap Pembelajaran Dengan Pendekatan Open-Ended Problem Pada Grafik Fungsi Eksponen

\begin{tabular}{|c|c|c|c|c|c|c|c|c|c|}
\hline No. Item*) & Sifat & SS & S & RR & TS & STS & Skor Total & Skor Rata-rata & Kriteria \\
\hline $\mathbf{1}$ & Positif & 5 & 23 & 2 & 0 & 0 & 123 & 4,10 & SP \\
\hline $\mathbf{2}$ & Positif & 2 & 25 & 3 & 0 & 0 & 119 & 3,97 & P \\
\hline $\mathbf{3}$ & Positif & 15 & 14 & 0 & 1 & 0 & 133 & 4,43 & SP \\
\hline $\mathbf{4}$ & Positif & 19 & 10 & 1 & 0 & 0 & 138 & 4,60 & SP \\
\hline $\mathbf{5}$ & Positif & 8 & 21 & 1 & 0 & 0 & 127 & 4,23 & SP \\
\hline $\mathbf{6}$ & Positif & 6 & 22 & 2 & 0 & 0 & 124 & 4,13 & SP \\
\hline $\mathbf{7}$ & Positif & 17 & 13 & 0 & 0 & 0 & 137 & 4,57 & SP \\
\hline $\mathbf{8}$ & Positif & 18 & 12 & 0 & 0 & 0 & 138 & 4,60 & SP \\
\hline $\mathbf{9}$ & Positif & 21 & 7 & 0 & 0 & 0 & 143 & 4,77 & SP \\
\hline $\mathbf{1 0}$ & Positif & 18 & 12 & 0 & 0 & 0 & 138 & 4,60 & SP \\
\hline $\mathbf{1 1}$ & Positif & 15 & 15 & 0 & 0 & 0 & 135 & 4,50 & SP \\
\hline $\mathbf{1 2}$ & Positif & 19 & 11 & 0 & 0 & 0 & 139 & 4,63 & SP \\
\hline $\mathbf{1 3}$ & Positif & 15 & 14 & 1 & 0 & 0 & 134 & 4,47 & SP \\
\hline $\mathbf{1 4}$ & Positif & 17 & 13 & 0 & 0 & 0 & 137 & 4,57 & SP \\
\hline $\mathbf{1 5}$ & Positif & 15 & 14 & 1 & 0 & 0 & 134 & 4,47 & SP \\
\hline $\mathbf{1 6}$ & Positif & 16 & 14 & 0 & 0 & 0 & 136 & 4,53 & SP \\
\hline $\mathbf{1 7}$ & Positif & 12 & 17 & 1 & 0 & 0 & 131 & 4,37 & SP \\
\hline $\mathbf{1 8}$ & Positif & 16 & 13 & 1 & 0 & 0 & 135 & 4,50 & SP \\
\hline $\mathbf{1 9}$ & Positif & 17 & 9 & 4 & 0 & 0 & 133 & 4,43 & SP \\
\hline $\mathbf{2 0}$ & Positif & 22 & 8 & 0 & 0 & 0 & 142 & 4,73 & SP \\
\hline
\end{tabular}

1. Sava senang belaiar Matematika

Keterangan : *), SP = Sangat Positf, $\mathrm{P}=$ Positif mtika.

3. saya senang mempelajarı graruık rungsi eksponen secara berkelompok

4. Saya senang, jika pembelajaran grafik fungsi eksponen menggunakan pendekatan open-ended problem di kelas ini, tetap dipertahankan untuk topik-topik berikutnya

5. Perbedaan pendapat dalam memberikan jawaban benar pada masalah grafik fungsi eksponen dengan pendekatan open-ended problem tidak membingungkan

6. Saya senang mempelajari grafil fungsi eksponen yang dimulai dengan masalah/soal

7. Pembelajaran dengan pendekatan open-ended problem pada materi grafik fungsi eksponen dapat menumbuhkan kreativitas pembelajaran.

8. Ada persoalan grafik fungsi eksponen dapat mempunyai lebih dari satu jawaban atau penyelesaian yang benar

9. Dengan pendekatan open-ended problem yang diterapkan di kelas ini kesulitan saya dalam menggambar dan memahami sifat-sifat grafik fungsi eksponen dapat terbantu

10. Soal/masalah dengan satu cara penyelesaian tidak memberi kebebasan berpikir.

11. Cara guru mengajar dengan pendekatan open ended problem menjadikan saya lebih memahami sifat-sifat grafik fungsi eksponen

12. Pembelajaran dengan pendekatan open ended problem pada materi grafik fungsi eksponen sangat efektif

13. Saya senang mengerjakan soal grafik fungsi eksponen yang dapat dijawab benar dengan banyak cara

14. Saya senang belajar seperti ini, karena jawabannya benar daripada satu, sehingga saya tidak terikat pada satu jawaban benar

15. Saya menyukai cara belajar Matematika di kelas ini dengan menghargai pendapat diantara temen-teman

16. Melalui pembelajarn Matematika yang diterapkan di kelas ini, pemahaman saya terhadap sketsa dan sifatsifat grafik eksponen meningkat

17. Cara mengajar menggunakan pendekatan open ended problem menjadikan saya lebih senang materi grafik fungsi eksponen

18. Saya senang jika pembelaharan grafik fungsi eksponen tetap dilakukan dengan cara seperti ini

19. Saya senang jika pembelajarn materi lain juga dilakukan dengan cara seperti ini

20. Pembelajaran dengan pendekatan open ended problem pada grafik fungsi eksponen yang digunakan guru menurut saya memiliki banyak kelebihan 
Respon siswa : $4 \leq \mathrm{x}<5$ = Sangat Positif, $3 \leq \mathrm{x}<4$ = Positif, $2 \leq \mathrm{x}<3$ = Negatif, $1 \leq \mathrm{x}<2$ = Sangat Negatif Berdasarkan tabel 6 terlihat bahwa 20 item penyataan yang disajikan, rata-rata siswa yang menyatakan sangat setuju 15.50 siswa $(51,67 \%)$, setuju 13,85 siswa $(46,17 \%)$, ragu-ragu 0,57 siswa ( $5,7 \%)$, tidak setuju 0,03 siswa $(3,33 \%)$, dan tidak ada siswa yang menyatakan sangat tidak setuju. Skor rata-rata kumulatif adalah 4,49 dan tergolong dalam kriteria sangat positif.

\section{Pembahasan}

Strategi pembelajaran matematika tiga tahapan yang terbagi dalam dua periode, yaitu periode pertama terdiri dari tahap awal yang merupakan fase orientasi atau fase pengenalan untuk menggali pengetahuan awal siswa (Khabibah dalam Hobri,2009:89-90). Periode kedua terdiri dari tahap inti yang merupakan fase eksplorasi, fase elaborasi dan fase konfirmasi, sedangkan tahap akhir merupakan fase tindakan oleh guru untuk mengetahui penguasaan siswa terhadap materi yang disajikan. Strategi pembelajaran matematika tiga tahapan yang diterapkan dalam pembelajaran matematika dengan pendekatan open-ended problem dapat menjadikan siswa mudah dibimbing dan diarahkan. Menurut Sawada (dalam Shimada, 1997:23), pendekatan open - ended problem memberikan kesempatan siswa untuk memperoleh pengetahuan melalui pengalaman menemukan, mengenali, dan memecahkan masalah dengan menggunakan beberapa cara, sehingga cara berpikir siswa dapat terlatih dengan baik. Dalam pembelajaran tersebut siswa juga merasa tidak terbebani dalam mempelajari materi grafik fungsi eksponen, karena pendapatnya merasa dihargai dan bebas mengungkapkannya, sehingga proses berpikir kreatif dalam menyelesaikan masalah/soal tumbuh dalam diri siswa. Selanjutnya menurut Suherman (2001:114), bahwa pendekatan open-ended problem memberikan keleluasaan kepada siswa untuk mengemukakan jawaban dan lebih bersifat merangsang tumbuhnya kreativitas berpikir siswa.

Keunikan dari strategi pembelajaran matematika tiga tahapan yang digunakan penulis dalam pembelajaran dengan pendekatan open-ended problem pada grafik fungsi eksponen terjadi pada saat masuk pada fase eksplorasi, yaitu penulis mengeksplorasi kemampuan siswa secara individu untuk memecahkan dan menyelesaikan masalah yang diajukan penulis dengan menggunakan LKS, sebelum siswa bekerja secara berkelompok. Jadi siswa mempunyai kesiapan materi yang cukup untuk selanjutnya melaksanakan diskusi kelompok.

Penggunaan LKS dalam pembelajaran bertujuan untuk membantu pemahaman siswa terhadap masalah (problem) yang diajukan guru dan membantu guru untuk menumbuhkan kreativitas siswa serta mengarahkan pemikiran munculnya respon/jawaban yang diharapkan. Tumbuhnya kreativitas siswa, khususnya munculnya sikap kreatif dan berpikir kreatif yang ditunjukkan siswa selama mengikuti pembelajaran dan dapat dilihat dari hasil observasi pada penelitian yang dilakukan oleh penulis bersama observer.

Menurut Sternberg \& Lubart ( dalam Aziz, 2010:25) menyebutkan karakteristik dan ciri-ciri sikap kreatif, yaitu (1) keterbukaan terhadap pengalaman baru, (2) keberanian untuk menanggung resiko/kritikan, (3) keteguhan terhadap pendirian, dan toleransi terhadap ketaksaan. Aspek sikap kreatif yang ditunjukkan siswa selama pembelajaran: (1) keterbukaan terhadap pengalaman baru diwujudkan dengan siswa mau dan mampu berdiskusi dalam kelompok, tercatat 28 siswa yaitu 93,3\% dari 30 siswa, sedangkan 2 siswa masih bekerja secara individual dan telah ditangani peneliti dengan secara langsung datang dan berinteraksi ke kelompoknya, (2) keberanian untuk menanggung resiko/kritikan diwujudkan dengan siswa berani mengemukakan gagasan/pendapat dalam diskusi kelompok, tercatat semua siswa berani mengemukakan pendapatnya, meskipun tercatat 16 siswa yaitu 53,3\% dari 30 siswa bersifat saling melengkapi gagasan/pendapat dari anggota lain, (3) keteguhan terhadap pendirian diwujudkan dengan siswa percaya diri dalam mengerjakan tes akhir tindakan, tercatat semua siswa mengerjakan 3 butir soal yang diujikan dan 23,3\% dari 30 siswa mengerjakan dengan benar 3 butir soal, 16,7\% dari 30 siswa mengerjakan dengan benar 2 butir soal dan 1 butir soal yang lain dikerjakan tetapi masih terdapat beberapa kesalahan, 50\% dari 30 siswa mengerjakan dengan benar 1 butir soal dan 2 butir soal yang lain dikerjakan tetapi masih 
terdapat beberapa kesalahan, 13,3\% dari 30 siswa mengerjakan 3 butir soal, tetapi masingmasing butir soal masih terdapat beberapa kesalahan, (4) toleransi terhadap ketaksaan diwujudkan dengan siswa memberi tanggapan dan menghargai pendapat dari siswa lain/ kelompok lain, tercatat $26,7 \%$ dari 30 siswa selalu memberi tanggapan pendapat dari siswa lain/ kelompok lain, 33,3\% dari 30 siswa sering memberi tanggapan pendapat dari siswa lain/ kelompok lain, dan $40 \%$ dari 30 siswa kadang-kadang memberi tanggapan pendapat dari siswa lain/ kelompok lain.

Menurut Baer (dalam Munandar, 2009) menjelaskan tiga kriteria berpikir kreatif, yaitu (1) keterampilan berpikir lancar (fluency), (2) keaslian (originality), dan (3) keterampilan berpikir luwes (flexibility). Aspek berpikir kreatif yang ditunjukkan siswa selama pembelajaran: (1) keterampilan berpikir lancar diwujudkan dengan siswa mampu menjawab/merespon masalah dengan benar lebih dari satu jawaban, tercatat 63,3\% dari 30 siswa mampu menjawab masalah dengan benar lebih dari satu jawaban, 33,3\% dari 30 siswa mampu menjawab masalah dengan benar hanya satu jawaban dan 1 siswa menjawab salah, (2) keaslian diwujudkan dengan siswa mampu mengemukakan secara tertulis jawaban benar dari masalah yang disajikan, tercatat $23,3 \%$ dari 30 siswa dapat menggambar dengan benar grafik fungsi eksponen lebih dari 3 buah dan mampu menuliskan sifat-sifat grafik fungsi eksponen dengan benar, 16,7\% dari 30 siswa dapat menggambar dengan benar grafik fungsi eksponen sebanyak 3 buah dan mampu menuliskan sifat-sifat grafik fungsi eksponen dengan benar, 10\% dari 30 siswa dapat menggambar dengan benar grafik fungsi eksponen sebanyak 2 buah dan mampu menuliskan sifat-sifat grafik fungsi eksponen dengan benar, 50\% dari 30 siswa dapat menggambar dengan benar grafik fungsi eksponen sebanyak 1 buah dan mampu menuliskan sifat-sifat grafik fungsi eksponen dengan benar, dan 1 siswa menjawab salah, (3) keterampilan berpikir luwes diwujudkan dengan siswa mampu memberikan alternatif jawaban benar terhadap penyelesaian yang disajikan, tercatat sekitar 16,7\% dari 30 siswa dapat memberikan lebih dari 6 alternatif jawaban benar, 13,3\% dari 30 siswa dapat memberikan sebanyak 5-6 alternatif jawaban benar, 33,3\% dari 30 siswa dapat memberikan sebanyak 2-4 alternatif jawaban benar, 33,3\% dari 30 siswa dapat memberikan sebanyak 1 alternatif jawaban benar dan 1 siswa menjawab salah.

Secara umum siswa telah mampu bersikap kreatif dan berpikir kreatif selama mengikuti tahapan pembelajaran di kelas dan mencari solusi pemecahan masalah yang disajikan. Siswasiswa yang kesulitan dalam mencari solusi pemecahan masalah open-ended yang disajikan, setelah didistribusikan kedalam kelompok siswa-siswa tersebut mulai bisa beradaptasi dan berinteraksi dengan anggota kelompoknya dalam memahami masalah yang disajikan, meskipun masih perlu ada bimbingan dari guru.

Berdasarkan hasil observasi yang telah dilakukan oleh kedua orang observer menyatakan bahwa secara umum respon siswa terhadap pembelajaran dengan pendekatan open-ended problem pada grafik fungsi eksponen menunjukkan respon yang positif. Pernyataan tersebut dikuatkan oleh hasil angket yang telah diberikan kepada siswa di akhir pembelajaran pada siklus I dan wawancara yang dilakukan oleh peneliti dengan siswa. Respon positif siswa tersebut ditunjukkan oleh adanya rasa senang siswa, diantaranya adalah bertepuk tangan ketika jawaban mereka benar, jika ada hal yang belum dimengerti mereka mau bertanya, keceriaan wajah siswa selama pembelajaran berlangsung, dan sebagainya. Kepositifan respon siswa terhadap pembelajaran dengan pendekatan open-ended problem pada grafik fungsi eksponen, karena selama proses pembelajaran pendapat dan pemikiran mereka yang beragam merasa dihargai. Keragaman pendapat tersebut dapat memberi kesempatan kepada siswa untuk memperoleh pengalaman sebanyak-banyaknya dalam upaya menemukan penyelesaian masalah berdasarkan gagasan dari siswa lain.

\section{KESIMPULAN}

Pembelajaran dengan pendekatan open-ended problem pada grafik fungsi eksponen dapat menumbuhkan kreativitas siswa pada aspek sikap kreatif dan berpikir kreatif melalui 
strategi pembelajaran dua periode yang mengintegrasikan tiga tahapan pembelajaran, yaitu periode pertama untuk tahap awal: fase orientasi, periode kedua untuk tahap inti: fase eksplorasi, fase elaborasi dan fase konfirmasi, dan tahap akhir.

Melalui penggunaan LKS siswa merasa lebih mudah memahami masalah yang disajikan dan guru merasa mudah mengarahkan pemikiran siswa untuk memperoleh respon/jawaban benar terhadap masalah yang disajikan. Respon siswa terhadap pelaksanaan pembelajaran dengan pendekatan open-ended problem pada grafik fungsi eksponen kepada siswa kelas XII IPA-1 SMA Negeri 1 Tanjung Selor dan dikuatkan dengan hasil wawancara dengan siswa menunjukkan respon yang positif. Aktivitas guru selama proses pembelajaran dengan pendekatan open-ended problem pada grafik fungsi eksponen menunjukkan aktivitas yang baik. Berdasarkan hasil observasi yang dilakukan oleh dua orang observer terhadap kreativitas siswa pada aspek sikap kreatif dan berpikir kreatif menunjukkan bahwa 73,5\% dari 30 siswa kelas XII IPA-1 masuk dalam kategori kreatif.

Berdasarkan hasil refleksi selama tindakan siklus I, maka penelitian untuk menumbuhkan kreativitas siswa dengan pendekatan open-ended problem melalui pembelajaran fungsi eksponen telah berhasil mencapai target yang disyaratkan oleh ketiga indikator keberhasilan dalam penelitian dan kegiatan penelitian diakhiri.

\section{DAFTAR PUSTAKA}

Aziz, R. (2010). Psikologi Pendidikan. Malang: UIN-Maliki Press.

Ghony, M. (2008). Penelitian Tindakan Kelas. Malang: UIN-Malang Press.

Hobri. (2009). Model-Model Pembelajaran Inovatif. Jember: FKIP Universitas Jember.

Muhsetyo, G. (2004). Pembelajaran Matematika Berbasis Kompetensi. Jurnal Matematika atau Pembelajaran. X (2): 125-139.

Munandar, U. (2009). Pengembangan Kreativitas Anak Berbakat. Jakarta: Rineka Cipta.

Moleong, L.J. (2007). Metodologi Penelitian Kualitatif. Bandung: PT. Remaja Rosdakarya.

Shimada, S. (1997). The Significance of Open-Ended Approach.Dalam J.P.Becker \& S.Shimada (Ed). The Open-Ended Approach:A New Proposal for Teaching Mathematics. Virginia: The National of Council of Teachers of Mathematics. 